\title{
Incidence and causes of sudden death in a university hospital in eastern Saudi Arabia
}

H.K. Nofal, ${ }^{1}$ M.F. Abdulmohsen ${ }^{2}$ and A.H.Khamis ${ }^{3}$

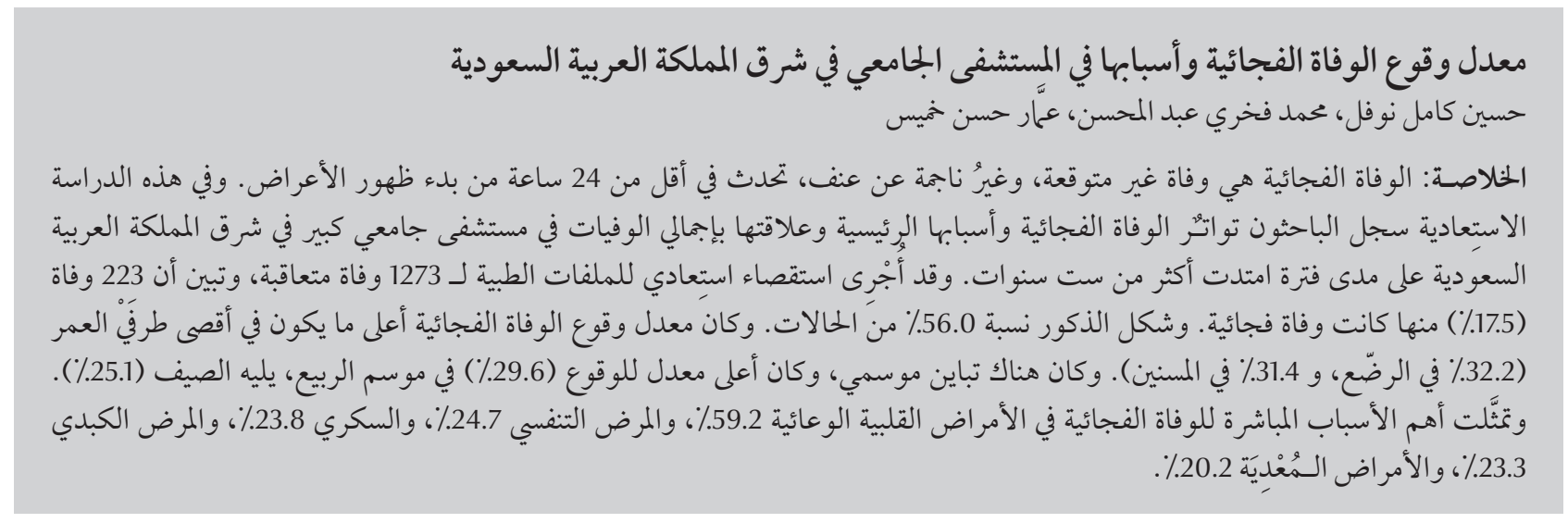

ABSTRACT Sudden death is non-violent, unexpected death occurring less than 24 hours from the onset of symptoms. In this retrospective descriptive study we report the frequency and main causes of sudden deaths in relation to total deaths at a large university hospital in the Eastern region of Saudi Arabia over a 6-year period. The medical files of 1273 consecutive deaths were retrospectively investigated and showed $223(17.5 \%)$ cases of sudden death. Males were $56.0 \%$ of cases. The incidence of sudden death was highest in the 2 age extremes $(32.2 \%$ were infants and 31.4\% were elderly). There was a seasonal variation, with the highest incidence (29.6\%) during spring followed by summer $(25.1 \%)$. The most important direct causes of sudden death were cardiovascular diseases in $59.2 \%$ of cases, respiratory disease in $24.7 \%$, diabetes mellitus in $23.8 \%$, liver disease in $23.3 \%$ and infectious disease in $20.2 \%$.

\section{Incidence et causes de mort subite dans un hôpital universitaire de l'est de l'Arabie saoudite}

RÉSUMÉ La mort subite correspond à un décès non violent et inattendu survenant moins de 24 heures après l'apparition de symptômes. Dans la présente étude descriptive rétrospective, nous avons examiné la fréquence et les causes principales des morts subites par rapport au nombre total des décès dans un grand hôpital universitaire de la région orientale de l'Arabie saoudite, sur une période de six ans. Les dossiers médicaux de 1273 patients dont les décès ont été consécutifs, ont été étudiés rétrospectivement. Parmi ceux-ci, 223 (17,5\%) étaient des cas de mort subite. Les hommes représentaient $56,0 \%$ des cas. L'incidence des morts subites était maximale dans les deux tranches d'âge extrême (32,2 \% étaient des nourrissons et 31,4 \% des personnes âgées). Une variation saisonnière a pu être observée, avec une incidence maximale $(29,6 \%)$ au printemps, puis en été $(25,1 \%)$. Les principales causes directes étaient les maladies cardio-vasculaires pour 59,2\% des cas, les affections respiratoires pour $24,7 \%$, le diabète sucré pour $23,8 \%$, les affections hépatiques pour $23,3 \%$ et les maladies infectieuses pour $20,2 \%$.

${ }^{7}$ Department of Pathology/Forensic Medicine; ${ }^{2}$ Department of Internal Medicine; ${ }^{3}$ Department of Family and Community Medicine, College of Medicine, King Faisal University, Dammam, Saudi Arabia (Correspondence to M.F. Abdulmohsen:fakhri_fakhria@yahoo.com).

Received: 04/08/09; accepted: 03/12/09 


\section{Introduction}

Despite tremendous technological advances in health care the phenomenon of sudden death is still a concern. The diagnosis and definition of sudden death are variable, but the generally recognized definition is based on the length of time between the onset of symptoms and death $[1,2]$. The World Health Organization (WHO) definition of sudden death according to the International classification of diseases, version 10 (ICD-10) is death, non-violent and not otherwise explained, occurring less than 24 hours from the onset of symptoms [2]. Cases of sudden death have been described in studies in a number of countries [3-9]. Sudden death occurs in all age groups: in infants (where it is called sudden infant death syndrome), in children and youths, in adults and in the elderly [9-16]. The risk factors for sudden death include: older age, low and high body mass index, arterial hypertension, diabetes mellitus, smoking, sedentary lifestyle, unhealthy diet and stress [17-19]. There are also seasonal variations in sudden death, with the highest frequency reported in winter, followed by autumn, spring and summer [20].

The nature of sudden death means that an accurate diagnosis is difficult to achieve without an autopsy $[1,2,21]$. In Saudi Arabia, however, postmortems are extremely limited for religious and cultural reasons regulations. Postmortems are performed in only a few centres around the country and only if there are medico-legal issues surrounding the death, such as a violent cause of death. Otherwise, routine postmortems are not carried out for religious and cultural reasons. Lack of postmortem can sometimes make the diagnosis of the cause of sudden death a difficult task. Unfortunately, there have been no epidemiological or even hospital-based studies about the incidence, mode and causes of sudden death in Saudi Arabia. Among the few reports of sudden death found during the literature search, one concerned 51 cases of "unexplained sudden death syndrome" reported to the medicolegal centre in Dammam, Saudi Arabia [22], another was about a Saudi family with 2 members having a rare congenital disorder [23] and in a third study the investigators tried to elucidate the role of inflammatory mediators in sudden deaths in adults and older children [24]. It was our aim therefore to conduct a cross-sectional hospital-based study of the incidence and main underlying causes of sudden death in a large university hospital located in the Eastern region of Saudi Arabia.

\section{Methods}

A retrospective analytical clinical study was undertaken of sudden deaths in all age groups at King Fahd Hospital of the University, Al Khobar, Saudi Arabia. Permission to conduct the study was received from the research committees of both the College of Medicine, King Faisal University and King Fahd Hospital of the University, Al Khobar.

We retrospectively investigated all 1273 deaths that occurred between 1 January 2000 and 31 December 2005. Deaths were classified as sudden deaths when the patient died unexpectedly from non-violent causes within 24 hours from the onset of the symptoms of their final clinical presentation; the remainder were classified as expected deaths. In all cases of sudden death, personal information, history of preexisting diseases, chief complaint(s) on presentation, clinical signs, medical investigations performed, diagnosis of death and time elapsed between the onset of prodromal symptoms and the onset of death were obtained from the medical records.

Individuals who arrived dead at the hospital were excluded from the study.

We stratified the incidence of sudden death in relation to all-cause deaths. We also tried to establish if there was any association of sudden and expected deaths with age group, sex, nationality, season and direct cause of death.

Data were entered into a computer using SPSS for Windows, version 13.0. The results were cross-tabulated to examine the relationships between the variables.

Statistical analysis was performed using the chi-squared test of association and Fisher exact test, as appropriate. Where multiple variables were examined, logistic regression analysis was used. Frequency tables were performed as descriptive statistics. A $P$-value $<0.05$ was considered significant in all statistical analyses

\section{Results}

Out of the 1273 deaths there were 223 cases of sudden death and 1050 cases of expected death during the 6-year study period. The incidence of sudden death as a proportion of all-cause deaths was therefore $17.5 \%$ compared with $82.5 \%$ for expected deaths. Sudden death occurred to 125 males (56.0\%), 94 females (42.2\%) and 4 cases of unrecorded sex (1.8\%). Out of 223 cases, there were 166 Saudis (74.4\%) and $57(25.6 \%)$ non-Saudis. The great majority were Muslims (97.5\%)

Table 1 illustrates the age distribution of sudden deaths in this study: $21.4 \%$ were newborns, $3.6 \%$ neonates, $6.7 \%$ infants and $5.3 \%$ aged $1-18$ years. Young adults (aged 18-39 years) were $9.9 \%$ of cases, the middle aged (40-60 years) were $21.0 \%$, while the elderly (> 60 years) were $31.4 \%$.

The most frequent prior medical problems affecting the cases of sudden death in this study were: type 2 diabetes mellitus (21.5\%), hypertension (18.8\%) and cardiovascular disease (CVD) including stroke (15.2\%) (Table 2).

Table 3 shows the most frequent major prodromal symptoms preceding 
sudden death in the current study. These were: dyspnoea (shortness of breath) (25.1\% of cases), fever (11.7\%) and prematurity (10.8\%).

Table 4 shows the direct causes of sudden death: $59.2 \%$ of cases were attributed to cardiovascular disease, $24.7 \%$ respiratory disease, $23.8 \%$ diabetes mellitus, $23.3 \%$ liver disease and $20.0 \%$ infectious disease.

The mode of sudden death included cardiopulmonary arrest in the great majority of cases 190 (85.2\%) and respiratory arrest in 33 cases (14.8\%).

Figure 1 illustrates the seasonal variation of sudden and expected deaths in our patients. The highest frequency of sudden death occurred during the spring (April-June) (29.6\%), followed by summer (July-September) (25.1\%), as compared (10.6\%) and (18.3\%) respectively for expected deaths. The lowest frequency of sudden death occurred during autumn (October-December) and winter (January-March) with frequencies of $22.5 \%$ and $22.9 \%$, as compared with $36.8 \%$ and $34.4 \%$ for expected deaths (chi-squared $P<$ 0.001 ).

\section{Discussion}

Sudden unexpected death is a major public health problem in our region as other parts of the world. It affected $17.5 \%$ of the total cases of death in this university hospital in Eastern region, Saudi Arabia. This finding contrasts with the findings of Krahn et al., in Canada, who reported an incidence of $41 \%$ [25] and Goraya et al., who reported sudden cardiac death occurring in $61 \%$ of all cases of death due to coronary heart disease in the United States [26]. Nonetheless, another analysis of national and State-specific sudden cardiac death data in the US found that $63.4 \%$ of all cardiac death cases were sudden cardiac death [27].

In our study a higher proportion of sudden deaths were male than

\begin{tabular}{lcc}
\hline $\begin{array}{l}\text { Table } 1 \text { Age distribution of cases of sudden death in King Fahd Hospital of the } \\
\text { University (2000 to 2005) }\end{array}$ & $\begin{array}{c}\text { No. of cases } \\
(\boldsymbol{n}=\mathbf{2 2 3})\end{array}$ \\
\hline Age group & 72 & 32.2 \\
Infants (0-12 months) & 12 & 5.3 \\
Children and adolescents (1-18 years) & 22 & 9.9 \\
Young adults (19-39 years) & 47 & 21.0 \\
Middle aged adults (40-60 years) & 70 & 31.4 \\
\hline
\end{tabular}

\begin{tabular}{lcc}
\hline $\begin{array}{l}\text { Table } 2 \text { Important prior medical problems reported by the patient or their } \\
\text { companion in cases of sudden death }\end{array}$ & $\begin{array}{c}\text { No. of cases } \\
(\boldsymbol{n}=\mathbf{2 2 3})\end{array}$ & $\%$ \\
\hline Past medical history & 48 & 21.5 \\
Diabetes mellitus type 2 & 42 & 18.8 \\
Hypertension & 34 & 15.2 \\
Cardiovascular disease ${ }^{\mathrm{a}}$ & 17 & 7.6 \\
Pneumonia & 17 & 7.6 \\
Sepsis & 17 & 7.6 \\
Cancer & 15 & 6.7 \\
Congenital anomaly & 14 & 6.3 \\
Liver disease & 7 & 3.1 \\
Renal disease & 2 & 0.9 \\
Sickle-cell disease and G6PD deficiency & & \\
\hline
\end{tabular}

ancluding stroke; ${ }^{b}$ Including Down syndrome.

$G 6 P D=$ glucose-6-phosphate dehydrogenase .

\begin{tabular}{lcc}
\hline $\begin{array}{l}\text { Table } 3 \text { Most frequent prodromal symptoms on the initial presentation of cases of } \\
\text { sudden death }\end{array}$ & $\begin{array}{c}\text { No. of cases } \\
(\boldsymbol{n}=\mathbf{2 2 3})\end{array}$ \\
\hline Initial symptom & 56 & $\%$ \\
\hline Dyspnoea & 26 & 25.1 \\
Fever & 24 & 11.7 \\
Prematurity (infant) & 21 & 10.8 \\
Circulatory collapse & 17 & 9.4 \\
Angina & 16 & 7.6 \\
Cough & 12 & 7.2 \\
Coma & 12 & 5.4 \\
Anorexia & 10 & 5.4 \\
Weakness & 6 & 4.5 \\
Seizures & 5 & 2.7 \\
Diarrhoea & 2 & 2.2 \\
Abdominal distension & 2 & 0.9 \\
Dementia & & 0.9 \\
\hline
\end{tabular}

female (56.0\% versus $42.2 \%)$ and this is consistent with international experience $[3,18,26-31]$. Sudden deaths occurred in all age groups but the highest proportion were elderly patients above the age of 60 years (31.4\%), followed by infants (31.2\%) and the middle aged (21.0\%); the $1-18$ years age group were 


\begin{tabular}{|c|c|c|c|}
\hline \multicolumn{4}{|c|}{ Table 4 Direct causes of sudden death according to death certificates (2000 to } \\
\hline Rank & Direct cause & $\begin{array}{l}\text { No. of cases } \\
(n=223)\end{array}$ & $\%$ \\
\hline \multirow[t]{6}{*}{1} & Cardiovascular disease & 132 & 59.2 \\
\hline & $\begin{array}{l}\text { Coronary artery disease including acute } \\
\text { myocardial infarction }\end{array}$ & 49 & 22.0 \\
\hline & Hypertension & 38 & 17.0 \\
\hline & Stroke & 16 & 7.2 \\
\hline & Cardiogenic shock & 16 & 7.2 \\
\hline & Life-threatening cardiac arrhythmia & 13 & 5.8 \\
\hline \multirow[t]{5}{*}{2} & Respiratory disease & 55 & 24.7 \\
\hline & Pneumonia & 29 & 13.0 \\
\hline & Respiratory failure & 6 & 2.7 \\
\hline & Bronchial asthma & 4 & 1.8 \\
\hline & Chronic obstructive pulmonary disease & 4 & 1.8 \\
\hline 3 & Diabetes mellitus & 53 & 23.8 \\
\hline 4 & Liver disease & 52 & 23.3 \\
\hline 5 & Infectious disease & 45 & 20.2 \\
\hline 6 & Renal disease & 37 & 16.6 \\
\hline 7 & Congenital anomaly & 36 & 16.1 \\
\hline 8 & Cancer & 36 & 16.1 \\
\hline 9 & Prematurity & 28 & 12.6 \\
\hline 10 & Neuropsychiatric disease & 10 & 4.5 \\
\hline 11 & $\begin{array}{l}\text { Haematological disease including sickle-cell } \\
\text { disease and haemophilia }\end{array}$ & 5 & 2.2 \\
\hline 12 & $\begin{array}{l}\text { Immunological disorder including systemic } \\
\text { lupus erythematosus and rheumatoid arthritis }\end{array}$ & 5 & 2.2 \\
\hline
\end{tabular}

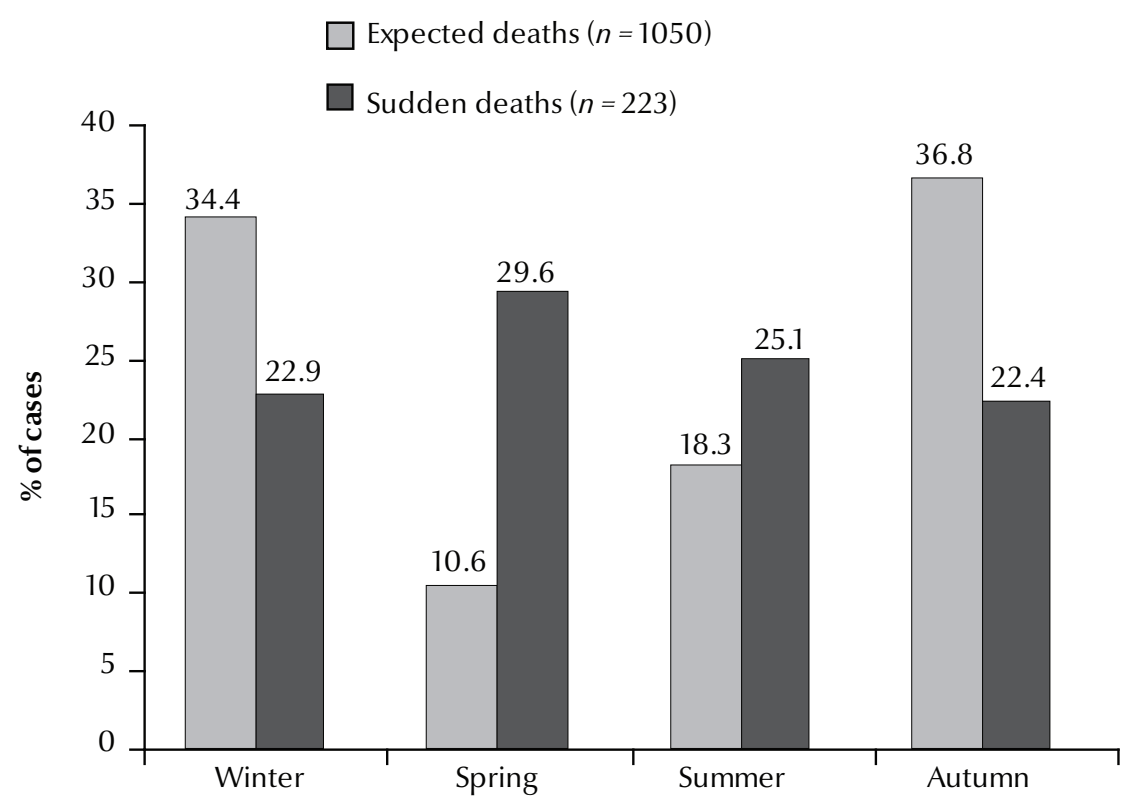

Figure 1 Seasonality of sudden and expected deaths (2000 to 2005) a much lower proportion (5.3\%). This age distribution of sudden death was also consistent with studies from other countries $[11,18,32]$.

There were a seasonal variation in natural sudden death among our cases with the highest frequency during spring (29.6\%), followed by summer $(25.1 \%)$, then autumn and winter (22.8\% each). This contrasts with the findings of Katz et al. in the Negev Desert region of Israel who found the highest rate in winter (31\%) and autumn (25\%) [20]. This might be explained by the difference between the cooler weather of the Mediterranean region and the very hot, windy and dusty weather during the spring and summer months in the Gulf region including eastern Saudi Arabia, which may exacerbate cardiovascular and respiratory diseases.

In agreement with other researchers, the most frequent past medical problem was CVD, including coronary heart disease, hypertension and stroke (34\% of cases) [17,18,26,27,30-35].

The most frequent prodromal symptoms in our study were: dyspnoea, fever, prematurity, circulatory collapse, angina and cough. These prodromal symptoms of sudden death in our study are to some extent different from the findings of other authors who found syncope [13], and congenital anomalies and low birth weight [15] were the main prodromal symptoms of sudden death. These differences may be related to the differences in the study population. However, dyspnoea represents a cardinal symptom of cardiovascular and respiratory diseases, which were the 2 main causes of sudden death, affecting $83.9 \%$ of our cases.

Our study also showed that the most important single direct cause of sudden death was CVD (59.2\%) and this is consistent with findings reported from developed countries [3, $17-19,26,27,30,31,34,35]$. Respiratory 
disease, especially bronchial asthma, chronic obstructive pulmonary disease and pneumonia, diabetes mellitus, liver disease, infectious disease, renal disease (especially end-stage renal disease), congenital anomaly, cancer and prematurity were also important direct causes of sudden death in the current study.

\section{Conclusion}

We found the incidence of sudden death was highest among the 2 age extremes, and also in hot, dusty and humid weather (late spring and early summer months). The most important prodromal symptoms prior to death were dyspnea, fever, low birth weight/ prematurity, circulatory collapse and angina. Therefore, we recommend the health care providers especially emergency physicians to pay attention to patients presenting with these prodromal symptoms, particularly infants and elderly patients.

\section{References}

1. Di Maio VJM, Di Maio DJ. Forensic pathology, 2nd ed. London, CRC Press, 2001.

2. International classification of diseases (ICD-10). Geneva, World Health Organization, 2005.

3. Sung RJ. Kuo Chi-Tai, Wa Shan-Nan, Lai WT, Luqman N, and Chan NY. Sudden cardiac death syndrome: age, gender, ethnicity, and genetics. Acta Cardiologica Sinica 2008, 24:65-74.

4. Spiliopoulou $\mathrm{C}$ et al. Clinical diagnoses and autopsy findings: a retrospective analysis of 252 cases in Greece. Archives of Pathology \& Laboratory Medicine, 2005, 129:210-214.

5. Morentin B et al. Incidencia y causas de muerte subita en menores de 36 anos [Incidence and causes of sudden death in persons less than 36 years of age]. Medicina Clínica, 2001, 116:294-295.

6. Kojima M et al. Sudden death of clinically unknown origin. An overview of postmortem examinations in Japan. Japanese Journal of Public Health, 1999, 46:563-568.

7. Nashelsky MB, Lawrence $\mathrm{CH}$. Accuracy of cause of death determination without forensic autopsy examination. American Journal of Forensic Medicine and Pathology, 2003, 24:313-319.

8. Blackwell CC et al. Sudden unexpected nocturnal deaths among Thai immigrant workers in Singapore. The possible role of toxigenic bacteria. International Journal of Legal Medicine, 1994, 106:205-208.

9. Eckart RE et al. Sudden death in young adults: a 25-year review of autopsies in military recruits. Annals of Internal Medicine, 2004, 141(11):829-834.

10. Morentin B et al. Sudden unexpected non-violent death between 1 and 19 years in north Spain. Archives of Disease in Childhood, 2000, 82:456-461.

11. Amital $\mathrm{H}$ et al. Clinical characteristics of unexpected death among young enlisted military personnel: results of a threedecade retrospective surveillance. Chest, 2004, 126:528-533.

12. Drory $Y$ et al. Sudden unexpected death in persons less than 40 years of age. American Journal of Cardiology, 1991, 68:1388-1392.

13. Kramer MR, Drori $Y$, Lev B. Sudden death in young soldiers. High incidence of syncope prior to death. Chest, 1988, 93:345-347.

14. Nidal Abu-Rashid. Samir Al-Jirf and Hyam Bashour. Causes of death among Syrian children using verbal autopsy. Eastern Mediterranean Health Journal, 1996, 2:440-448.

15. Mesleh RA et al. Changing trends in perinatal deaths at the Armed Forces Hospital, Riyadh, Saudi Arabia. Journal of $\mathrm{Ob}$ stetrics \& Gynaecology, 2001, 21:49-55.

16. Quigley F et al. A survey of the causes of sudden cardiac death in the under 35-year-age group. Irish Medical Journal, 2005, 98:232-235.

17. Tabib A, Loire R. Unexpected sudden death and coronary lesions. Apropos of 407 cases out of 1000 deaths in patients under 65 years of age. Archives des Maladies du Coeur et des Vaisseaux, 1993, 86:401-406.

18. Chahine R. Cardiovascular risk factors: smoking in the context of recent events in Lebanon. Santé (Montrouge, France), 1998, 8:109-112.

19. Farley TM et al. Combined oral contraceptives, smoking, and cardiovascular risk. Journal of Epidemiology and Community Health, 1998, 52:775-785.

20. Katz A et al. Seasonal variation in sudden death in the Negev desert region of Israel. IsraelMedical Association Journal, 2000, 2:17-21.

21. Perkins GD et al. Discrepancies between clinical and postmortem diagnoses in critically ill patients: an observational study. Critical Care, 2003, 7(6):R129-R132.

22. Elfawal MA. Sudden unexplained death syndrome. Medicine, Science, and the Law, 2000, 40:45-51.

23. Al Rakaf M, Zakzouk SM, Al Shahwan SA. Jervell and LangeNielsen QT syndrome: a case report from Saudi Arabia. International Journal of Pediatric Otorhinolaryngology, 1997, 39:163-168.

24. Al Madani O et al. Pyrogenic toxins of Staphylococcus aureus in sudden unexpected nocturnal deaths in adults and older children: factors influencing the control of inflammatory responses to toxic shock syndrome toxins. FEMS Immunology and Medical Microbiology, 1999, 25:207-219.

25. Krahn AD et al. Diminishing proportional risk of sudden death with advancing age: implications for prevention of sudden death. American Heart Journal, 2004, 147:837-840.

26. Goraya TY et al. Coronary heart disease death and sudden cardiac death: a 20-year population-based study. American Journal of Epidemiology, 2003, 157:763-770.

27. Murai T et al. Sudden death due to cardiovascular disorders: a review of the studies on the medico-legal cases in Tokyo. Keio Journal ofMedicine, 2001, 50:175-181.

28. Hecht A, Löffler D. Acute natural death in adults with special reference to the under-50 age group. Zentralblatt für Allgemeine Pathologie und Pathologische Anatomie, 1984, 129:127-135.

29. Tamakoshi K, Toyoshima H, Yatsuya H. Gender difference of sudden death. Japanese Journal of Clinical Medicine, 2005, 63:1284-1288.

30. Schatzkin A et al. Sudden death in the Framingham Heart Study. Differences in incidence and risk factors by sex and coronary disease status. American Journal of Epidemiology, 1984, 120:888-899.

31. Kawakubo K, Lee JS. Incidence rate of sudden death in Japan. Japanese Journal of Clinical Medicine, 2005, 63:1127-1134.

32. Loire R, Tabib A. Unexpected sudden cardiac death. An evaluation of 1000 autopsies. Archives des Maladies du Coeur et des Vaisseaux, 1996, 89:13-18. 
33. Scheffold T et al. Hypertrophe Kardiomyopathie [Hypertrophic cardiomyopathy]. Herz, 2005, 30:550-557.

34. Aktas EO et al. Variations in the papillary muscles of norma tricuspid valve and their clinical relevance in medicolegal autopsies. Saudi Medical Journal, 2004, 25:1176-1185.

35. Kocak A et al. Structure of the human tricuspid valve leaflets and its chordae tendineae in unexpected death. A forensic autopsy study of 400 cases. Saudi Medical Journal, 2004, 25:1051-1059.

36. Bowker TJ et al. Sudden, unexpected cardiac or unexplained death in England: a national survey. QJM : Monthly Journal of the Association of Physicians, 2003, 96:269-279.

\section{World health days in September}

World Suicide Prevention Day held on 10 September 2011 aims to promote worldwide commitment and action to prevent suicides. The theme for World Suicide Prevention Day for 2011 is Preventing Suicide in Multicultural Societies. On average, almost 3000 people commit suicide daily. For every person who completes a suicide, 20 or more may attempt to end their lives. The International Association for Suicide Prevention, together with WHO and other partners advocate for the prevention of suicidal behaviour, provision of adequate treatment and follow-up care for people who attempted suicide, as well as responsible reporting of suicides in the media. Further information about suicide prevention and World Suicide Prevention Day can be found at: http://www.whoint/mental_health/prevention/suicide/suicideprevent/and http://wwwiasp.info/index.php

World Rabies Day held on 28 September 2011 aims to highlight the impact of human and animal rabies and promote how to prevent and stop the disease by combating it in animals. Sponsors - the Alliance for Rabies Control and the United States Centers for Disease Control and Prevention - report that 55000 people die every year from rabies, an average of one death every 10 minutes. There are safe and effective vaccines available for people who have been bitten by an animal that might have the disease, but usage in developing countries is low due to the high cost. Further information about rabies and World Rabies Day can be found at: http://www.whoint/rabies/en/ and http://www.worldrabiesday.org/

World Heart Day held on 29 September 2011 aims to raise awareness about cardiovascular diseases which are the world's leading cause of death, claiming 17.1 million lives each year. The theme for World Health Day for 2011 is One World, One home, One Heart. In partnership with WHO, the World Heart Federation organizes awareness events in more than 100 countries - including health checks, organized walks, runs and fitness sessions, public talks, stage shows, scientific forums, exhibitions, concerts, carnivals and sports tournaments. Further information about cardiovascular diseases and World Heart Day can be found at: http://www.whoint/cardiovascular_diseases/en/index.html and http://www.world-heart-federation.org/ 